\title{
Investigation of Hybrid Electric Aircraft Operation on Battery Degradation
}

DOI:

10.1109/ESARS-ITEC.2018.8607617

\section{Document Version}

Accepted author manuscript

Link to publication record in Manchester Research Explorer

\section{Citation for published version (APA):}

Zhu, Q., Forsyth, A., \& Todd, R. (2019). Investigation of Hybrid Electric Aircraft Operation on Battery Degradation. In 2018 IEEE International Conference on Electrical Systems for Aircraft, Railway, Ship Propulsion and Road Vehicles and International Transportation Electrification Conference, ESARS-ITEC 2018 https://doi.org/10.1109/ESARS-ITEC.2018.8607617

\section{Published in:}

2018 IEEE International Conference on Electrical Systems for Aircraft, Railway, Ship Propulsion and Road Vehicles and International Transportation Electrification Conference, ESARS-ITEC 2018

\section{Citing this paper}

Please note that where the full-text provided on Manchester Research Explorer is the Author Accepted Manuscript or Proof version this may differ from the final Published version. If citing, it is advised that you check and use the publisher's definitive version.

\section{General rights}

Copyright and moral rights for the publications made accessible in the Research Explorer are retained by the authors and/or other copyright owners and it is a condition of accessing publications that users recognise and abide by the legal requirements associated with these rights.

\section{Takedown policy}

If you believe that this document breaches copyright please refer to the University of Manchester's Takedown Procedures [http://man.ac.uk/04Y6Bo] or contact uml.scholarlycommunications@manchester.ac.uk providing relevant details, so we can investigate your claim.

\section{OPEN ACCESS}




\section{Investigation of Hybrid Electric Aircraft Operation on Battery Degradation}

\author{
Qingwei Zhu \\ School of Electrical and Electronic \\ Engineering \\ The University of Manchester \\ Manchester, United Kingdom \\ Qingwei.Zhu@manchester.ac.uk
}

\author{
Andrew Forsyth \\ School of Electrical and Electronic \\ Engineering \\ The University of Manchester \\ Manchester, United Kingdom \\ Andrew.Forsyth@manchester.ac.uk
}

\author{
Rebecca Todd \\ School of Electrical and Electronic \\ Engineering \\ The University of Manchester \\ Manchester, United Kingdom \\ Rebecca.Todd@manchester.ac.uk
}

\begin{abstract}
Hybridizing aircraft propulsion systems through the addition of electrically driven fans and on-board battery storage has been shown in several studies to have the potential to significantly reduce aircraft fuel burn and emissions. This paper investigates how different hybrid electric aircraft (HEA) operation regimes may affect the lifetime of the battery electric storage system (ESS). Battery cycling tests emulating three widely proposed electric operation regimes -a constant power regime, a stepped power regime, and a ramped power regime- are conducted. The capacity degradation and internal dc resistance change of the cells under test are investigated. The tests show that the stepped power operation regime is better for retaining the capacity of ESS batteries; whereas the ramped power operation regime designed for maximum fuel saving tends to accelerate battery degradation most severely.
\end{abstract}

Keywords-battery energy storage system, capacity degradation, cycling tests, hybrid electric aircraft, operation regime

\section{INTRODUCTION}

To meet the aggressive international targets [1] for reducing fuel burn and emissions, the aircraft industry must adopt radical new technologies. One such approach is the use of hybrid electric propulsion techniques whereby the conventional jet engine is augmented by electrically driven fans, which are supplied from a battery energy storage system (ESS) through a highly efficient electrical power distribution and conversion system. A proportion of the aircraft propulsion power may then be provided electrically which has the advantage of being more energy efficient than a jet-engine and producing virtually no emissions. A disadvantage however is the relatively low energy density of battery storage in comparison with aviation fuel. A number of recent studies have therefore focused on identifying the optimum size and operating regime for a hybrid propulsion system to minimise the overall fuel burn and emissions.

Many of these studies consider an Airbus A320 sized aircraft flying a typical $900 \mathrm{~nm}$ [1-7] mission since this represents the largest part of the air transport activity by volume and accounts for a major part of the industry's emissions. For example, NASA investigated a conceptual hybrid electric aircraft (HEA) called SUGAR-Volt $[1,2]$ in their Subsonic Ultra Green Aircraft Research (SUGAR) studies. The Bauhaus Luftfahrt also proposed and assessed a number of HEA concepts, including a twin hybrid fan concept [3], a tri-fan concept [4] with two underwing turbo fans and an aft electric fan, and a quad-fan concept [5]. Besides, RollsRoyce North America and Georgia Tech proposed their EVE concept [6]. These studies indicate that with hybrid electric propulsion, a fuel saving of $14-25 \%$ could be achieved over a $900 \mathrm{~nm}$ mission. However, these hybrid electric airliners, as shown in Fig. 1, would require a massive on-board battery, which weighs $7.6-11.7$ tonnes and accounts for about $13.1 \%$ of the aircraft's take-off gross weight (TOGW). Furthermore, these studies assumed the use of next generation battery technology with an energy density of $1500 \mathrm{Wh} / \mathrm{kg}$, whereas today's best-performing cells offer around $250 \mathrm{Wh} / \mathrm{kg}[8,9]$. However, these studies did not consider the impact of different operating regimes on the degradation and lifetime $[10,11]$ of the batteries and this is likely to be an important issue due to the high cost of cells, particularly high performance cells.

The objective of this study is to investigate how the proposed operation regimes of future HEA will affect battery degradation and life. With Panasonic's high energy density NCR-18650B battery [12], three rounds of battery cycling tests emulating three widely proposed electric operation regimes for a HEA are undertaken: a constant power regime, a stepped power regime, and a ramped power regime. The impact on the battery degradation rate of these three operation regimes has been investigated.

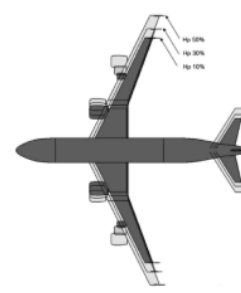

(a)

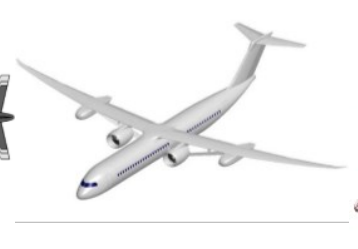

(b)

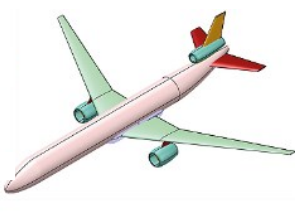

(c)
Fig. 1. Conceptual hybrid electric aircraft. (a) Bauhaus Luftfahrt quad-fan concept [5]. (b) NASA SUGAR-Volt concept [1]. (c) Bauhaus Luftfahrt trifan concept [4]. 


\section{COMMON ELECRIC OPERATION REGIMES OF HYBRID ELECTRIC AIRCRAFT}

This section summarizes the HEA conceptual studies proposed in the past decade, with a particular focus on the electric operation regime, that is the power profile of the ESS source. Airbus A320 and/or Boeing 737-800 like single-aisle hybrid electric airliners with a payload capacity of about 180 passengers (PAX), are considered because this part of the fleet accounts for the largest portion of aviation fuel consumption. Further, a market study from Airports Council International (ACI) reveals that, the A320 class airliners covering journeys of $900 \mathrm{~nm}, 1100 \mathrm{~nm}$, and $1300 \mathrm{~nm}$ represents 79\%, 85\%, and $90 \%$ respectively of all flights [5]. Therefore, almost all the published HEA studies [1-6] focus on missions of around $1000 \mathrm{~nm}$.

To achieve a fuel saving of around $15 \%$ on a $900 \mathrm{~nm}$ journey, a single-aisle HEA is estimated to require around $7 \mathrm{MWh}$ of battery energy storage, weighing over 10 tonnes. This is based on a battery energy density of $1500 \mathrm{Wh} / \mathrm{kg}$, which is thought to be an ambitious but realisable assumption for next generation battery technology. The battery system would typically supply two $2.3 \mathrm{MW}$ electric motor-driven fans.

The various studies suggest that operating the electrical propulsion system throughout the take-off, climb and cruise phases of a mission is likely to provide the best overall fuel saving, however a number of different load profiles have been considered for the electrical system. The most common is to operate the electrical propulsion system at a constant $[2,3]$, usually maximum, power throughout the flight, enabling the electrical system to remain at a maximum efficiency condition.

A second option is a stepped power profile as used in [5, $13,14]$, where, typically, the electrical system operates at a constant, high power during the take-off and climb phases of the flight and then drops to a lower constant power for the remainder of the flight. A profile of this sort allows the engine to be more optimally sized [5], bringing benefits in fuel consumption.

A third option for the power profile of the electrical system is to have a high constant power during the take-off and climb phases after which the power drops to much lower level, then gradually increases during the reminder of the flight. This has the advantage of allowing the engine to burn more fuel earlier in the flight, reducing the aircraft weight more quickly and resulting in a lower overall fuel consumption. A profile like this was used in the EVE concept study and resulted in one of the best reported fuel reductions of $25 \%$ [6].

\section{BATtery Cell CyCling TeStS EMUlating HEA OPERATION}

Three sets of battery cycling tests were designed to emulate the three most common electric operation regimes of an HEA. The cycling tests were undertaken on Panasonic's high energy density lithium-ion cells NCR-18650B [12].

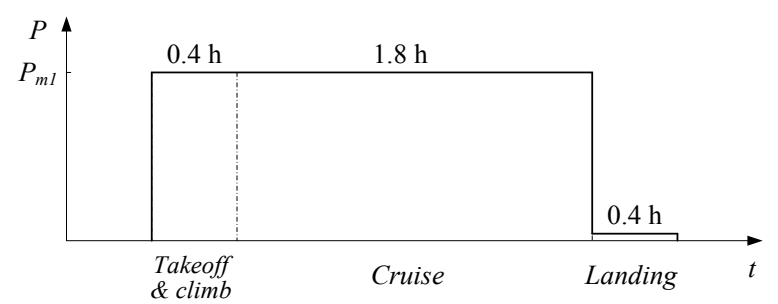

(a)

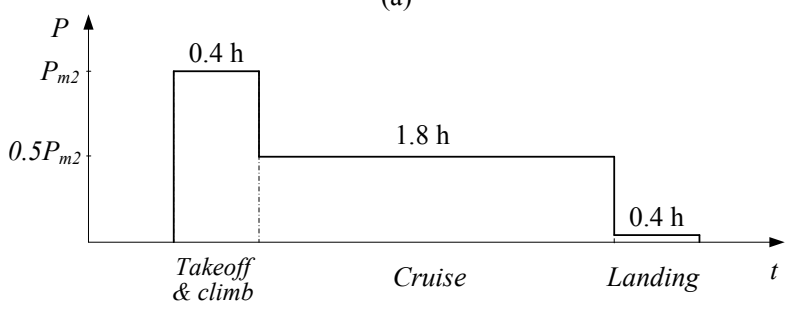

(b)

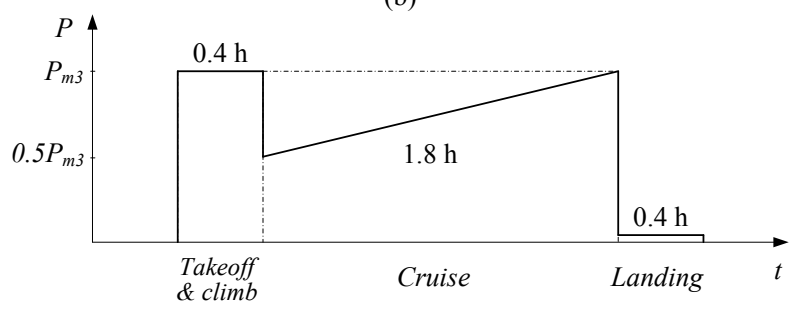

(c)

Fig. 2. Segment dependent electric power profiles of different HEA regimes for the $2.6 \mathrm{~h}$ examplary mission. (a) constant power operation regime, (b) stepped power operation regime, (c) ramped power operation regime.

\section{A. Power Profile Definition of the Three Typical Operation Regimes}

The tests assumed a 2.6h discharge cycle which corresponds to a $1000 \mathrm{~nm}$ flight by an A320 size aircraft, and is typical of the missions considered in the published HEA studies. In particular it is assumed that the flight comprises: $\sim 0.4 \mathrm{~h}$ for take-off \& climb (CL), $\sim 1.8 \mathrm{~h}$ for cruise (CR), and $\sim 0.4 \mathrm{~h}$ for landing. As in the published HEA studies, hybrid electric operation is not considered during the landing stage. The three electric propulsion regimes are illustrated in Fig. 2. They are:

1. Constant power (CP) regime: the ESS outputs a certain constant power $P_{m l}$ for $2.2 \mathrm{~h}$ throughout the takeoff, climb and cruise segments.

2. Stepped power (SP) regime: the ESS outputs its highest power $P_{m 2}$ in the $0.4 \mathrm{~h}$ takeoff $\&$ climb stage, then the electric power is maintained at half that level over the cruise segment.

3. Ramped power (RP) regime: the ESS outputs its highest power $P_{m 3}$ in the take-off \& climb stage, while the power during the cruise stage starts from $50 \%$ and rises linearly to $100 \%$ of $P_{m 3}$ at the end of the cruise phase. 


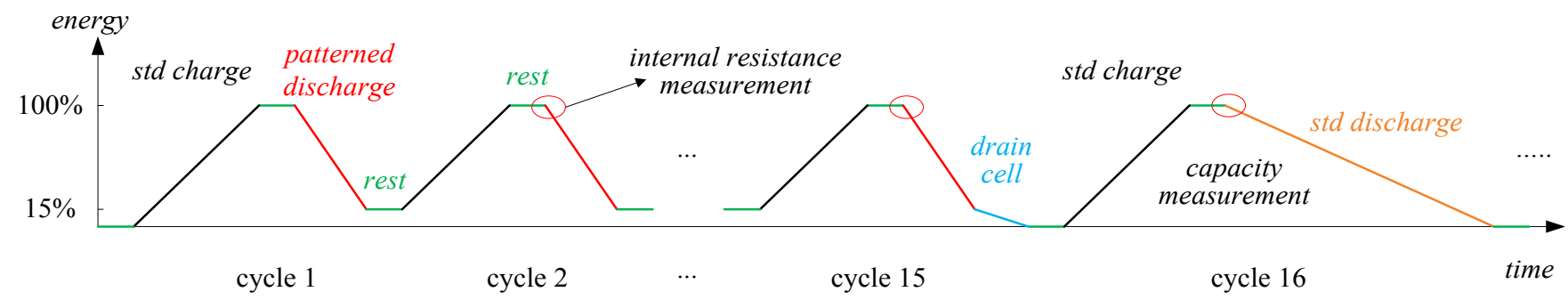

Fig. 3. HEA operation emulation cycling test process.

Assuming that the battery pack has the same total energy capacity $E$ for each profile, and that the battery depth of discharge is $85 \%$ at the end of each cycle, the power levels for each regime may be calculated using (1) to (6):

For the constant power operation regime:

$$
\begin{gathered}
2.2 \mathrm{~h} * P_{m 1}=0.85 E \\
P_{m 1}=\frac{0.85 E}{2.2 h}
\end{gathered}
$$

For the stepped power operation regime:

$$
\begin{gathered}
0.4 \mathrm{~h} * P_{m 2}+1.8 \mathrm{~h} * 0.5 P_{m 2}=0.85 E \\
P_{m 2}=\frac{0.85 E}{1.3 \mathrm{~h}}
\end{gathered}
$$

For the ramped power operation regime:

$$
\begin{gathered}
0.4 \mathrm{~h} * P_{m 3}+1.8 \mathrm{~h} * 0.5 *\left(0.5 P_{m 3}+P_{m 3}\right)=0.85 E \\
P_{m 3}=\frac{0.85 E}{1.75 h}
\end{gathered}
$$

\section{B. HEA Emulation Battery Cycling Tests and Measurements}

Three Panasonic NCR18650B [12] cells numbered \#1, \#2 and \#3 were subjected to the three discharge regimes. Cell \#1 was allocated to the constant power regime, cell \#2 the stepped power regime, and cell \#3 was tested with the ramped power regime. The NCR18650B cell was chosen for the tests because it is one of the highest energy density rechargeable batteries available in the market and is representative of the latest technology. This $48 \mathrm{~g}, 18650$ cell has a nominal capacity of $3250 \mathrm{mAh}$, and a specific energy density of $243 \mathrm{Wh} / \mathrm{kg}$.

Three standard charge/discharge cycles [13] (std cycle) were conducted at first on the cells to calibrate their initial dischargeable ampere-hour capacity $C_{\max 0}$ and energy storage capacity $E_{\max 0}$, seen in Table I. Then cycling tests emulating the three HEA operation regimes were undertaken according to the test process illustrated in Fig.3. A testing loop consists of 15 patterned charge/discharge cycles (patterned cycle), followed by a standard charge/discharge cycle. 12 loops were conducted in total, amounting to 192 cycles. The NHR9200 Series battery test system, which is able to precisely record the open circuit voltage (OCV), charge/discharge current, accumulated ampere-hour, watt-hour, and temperature data of the device under test (DUT), was used to conduct the tests. During the three tests the DUT was placed in a temperature chamber at a constant temperature of $25.3 \pm 0.2{ }^{\circ} \mathrm{C}$. A thermocouple was attached to the surface of each cell to measure the real-time temperature over the cycles.

Specifically, in a standard charge/discharge cycle, the fully drained cell is charged with a constant current of $0.5 \mathrm{C}$ at first until the open circuit voltage reaches $4.2 \mathrm{~V}$, then the cell is charged with the voltage fixed at $4.2 \mathrm{~V}$. Once the charging current tapers down to $65 \mathrm{~mA}$, the charging process ends. The cell is then kept in a rest state until it cools down to the chamber temperature. Then a constant current discharge starts at $0.2 \mathrm{C}$ until the cell OCV drops to its lower limit value of $2.5 \mathrm{~V}$. After that, the cell is kept in a rest state again until it cools down to the chamber temperature and the std cycle is completed.

In a patterned cycle, the cell starts with around 15\% energy remaining, it is first charged with $0.5 \mathrm{C}$ constant current until $4.2 \mathrm{~V}$, followed with the constant voltage charge just the same as in the std cycle. After allowing the fully charged cell to settle to the chamber temperature, the DUT is discharged following the patterned power profiles as shown in Fig. 2. The specific power profiles of cell \#1 (for the CP regime), cell \#2 (the SP regime), and cell \#3 (the RP regime), are calculated by substituting the total energy $E$ with their own initial energy capacity $E_{\max }$ in (2), (4), and (6), respectively. The patterned discharge takes $2.2 \mathrm{~h}$, and extracts $85 \%$ of the total energy when the cell is new. After the patterned discharge, the DUT is rested until its temperature settles to the chamber temperature. The current profiles of each patterned cycle corresponding to the three different operation regimes are plotted in Fig. 4, and the critical current/power parameters are summarized in Table I. $P_{m l, 2,3}$ is the maximum discharging power over a cycle, $I_{C L I}$ and $I_{C L 2}$ are the average current over the 180 patterned cycles measured at the start and the end of takeoff \& climb stage, $I_{C R I}$ and $I_{C R 2}$ are the average current over the 180 patterned cycles measured at the start and the end of cruise stage.

TABLE I. Summary of the Three Patterned Cycle Tests

\begin{tabular}{|c|c|c|c|c|c|c|c|c|}
\hline & $\begin{array}{c}\text { Cell } \\
\text { No. }\end{array}$ & $\begin{array}{c}\boldsymbol{P}_{m 1,2,3} \\
(\mathbf{W})\end{array}$ & $\begin{array}{c}I_{C L 1} \\
(\mathbf{A})\end{array}$ & $\begin{array}{c}\boldsymbol{I}_{C L 2} \\
(\mathbf{A})\end{array}$ & $\begin{array}{c}\boldsymbol{I}_{C R 1} \\
(\mathbf{A})\end{array}$ & $\begin{array}{c}\boldsymbol{I}_{C R 2} \\
(\mathbf{A})\end{array}$ & $\begin{array}{c}\boldsymbol{E}_{\max 0} \\
(\mathbf{W h})\end{array}$ & $\begin{array}{c}\boldsymbol{C}_{\max 0} \\
(\mathbf{m A h})\end{array}$ \\
\hline $\begin{array}{c}\text { Constant } \\
\text { power test }\end{array}$ & $\# 1$ & 4.5 & 1.089 & - & - & 1.402 & 11.61 & 3170 \\
\hline $\begin{array}{c}\text { Stepped } \\
\text { power test }\end{array}$ & $\# 2$ & 7.5 & 1.845 & 1.993 & 0.984 & 1.152 & 11.58 & 3166 \\
\hline $\begin{array}{c}\text { Ramped } \\
\text { power test }\end{array}$ & $\# 3$ & 5.6 & 1.366 & 1.444 & 0.715 & 1.821 & 11.50 & 3141 \\
\hline
\end{tabular}




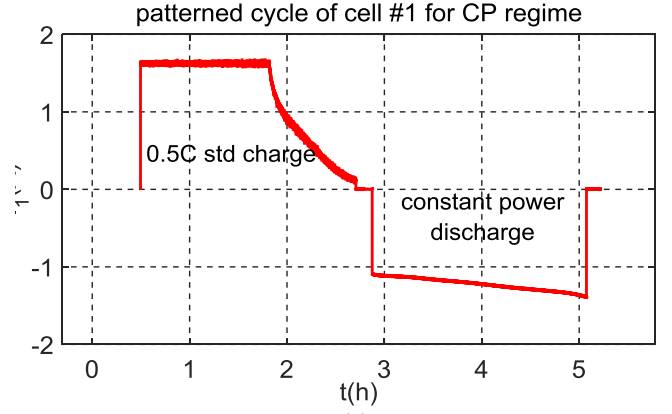

(a)

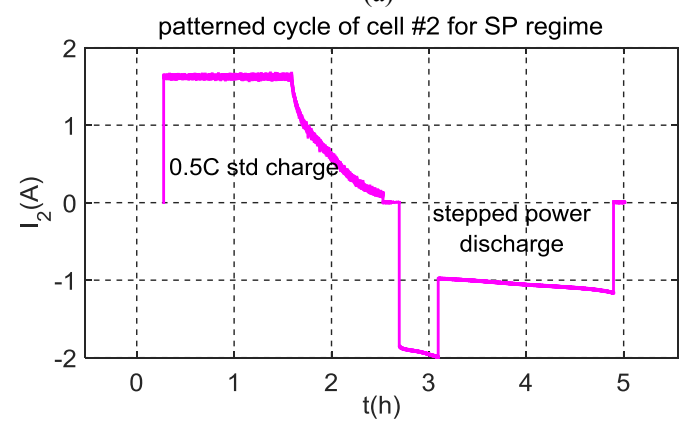

(b)

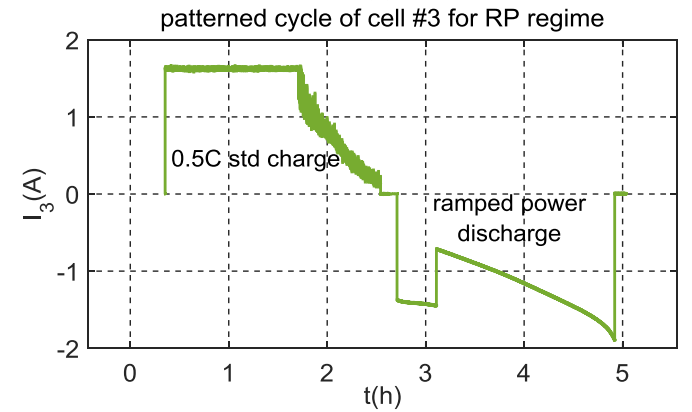

(c)

Fig. 4. Current profile of patterned charge/discharge cycles corresponding to the three operation regimes. (a) cell \#1: constant power (CP) operation, (b) cell \#2: stepped power (SP) operation, (c) cell \#3: ramped power (RP) operation.

The ampere-hour and energy in both the charging and discharging stages of each cycle were recorded during the tests. With these data the energy efficiency for each cycle has been evaluated. The data extracted from the 12 standard charge/ discharge cycles are used to evaluate the ampere-hour capacity and the energy storage capacity of the cells as they age.

Also, the current step at the beginning of the patterned discharge is used to calculate the internal resistance $R_{d c}$ of the cells at $100 \%$ state-of-charge (SoC) according to (7). $\left.\Delta U\right|_{\Delta t=1 \mathrm{~s}}$ is the voltage drop over one single sample interval as the data sampling rate was set as one second. $R_{d c}$ is evaluated for all of the 192 cycles.

$$
R_{d c}=\frac{\Delta U}{\Delta I}=\left|\frac{\left.\Delta U\right|_{\Delta t=1 s}}{I_{C L 1}}\right|
$$

\section{RESULTS AND DISCUSSION}

\section{A. Capacity Degradation}

The charged energy and ampere-hours measured from the 12 standard cycles are shown in Fig. 5. And the dischargeable energy and ampere-hours are shown in Fig. 6. The plots are normalized to the initial capacity in each case.

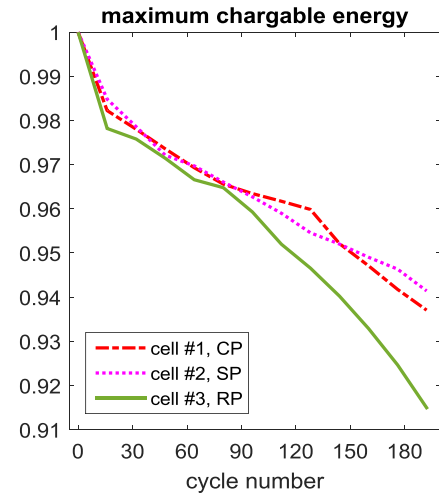

(a)

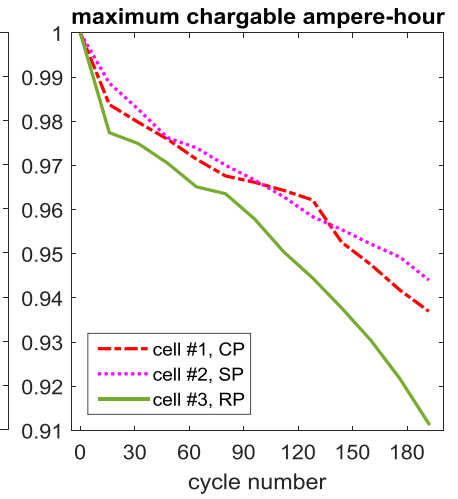

(b)
Fig. 5. Normalized chargeable capacity degradation of the cells under different operation regimes. (a) energy capacity, (b) ampere-hour capacity.

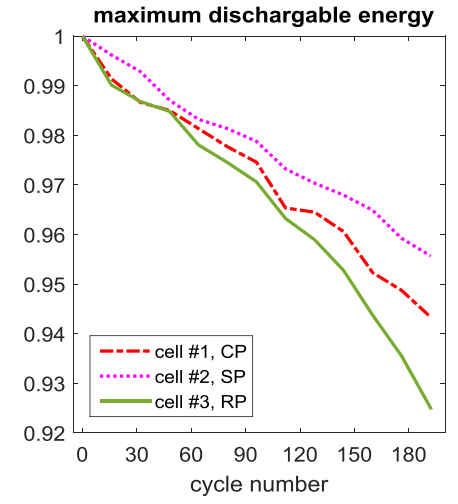

(a)

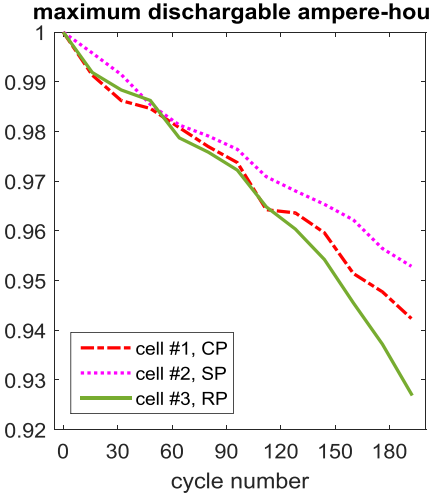

(b)
Fig. 6. Normalized dischargeable capacity degradation of the cells under different operation regimes. (a) energy capacity, (b) ampere-hour capacity.

In both Fig. 5 and Fig. 6, the degradation profiles of energy capacity closely resemble the corresponding degradation profiles of the ampere-hour capacity. Fig. 6 shows that, for cell $\# 1$, its energy capacity and ampere-hour capacity degraded to $94.4 \%$, and $94.2 \%$ of the initial capacity after 180 cycles of constant power operation, which corresponds to 180 aircraft flights. Cell \#2 which emulates the stepped power operation regime, achieved better results, with $95.5 \%$ of the energy and $95.3 \%$ of the ampere-hour capacity retained after 180 cycles. Whereas cell \#3 which was tested in the ramped power profile showed a much faster degradation, after the same number of cycles its energy and ampere-hour capacity dropped to $92.5 \%$ and $92.7 \%$ of the initial values.

The degradation rate for both the constant power and the stepped power regime, is seen to be approximately linear over the 192 cycles, and cell \#2 which was subjected to the stepped power regime shows the lowest degradation rate of the energy and ampere-hour capacity. Whereas for the ramped power test, the degradation rate appears to increase gradually with the cycle number and after about 110 cycles the normalised retained ampere-hour capacity of cell \#3 began to fall below that of cell \#1 and cell \#2. 


\section{B. Round trip Efficicency}

The calculated round trip energy efficiency of the 12 standard cycles and the 180 patterned cycles are shown in Fig. 7 and Fig. 8, respectively.

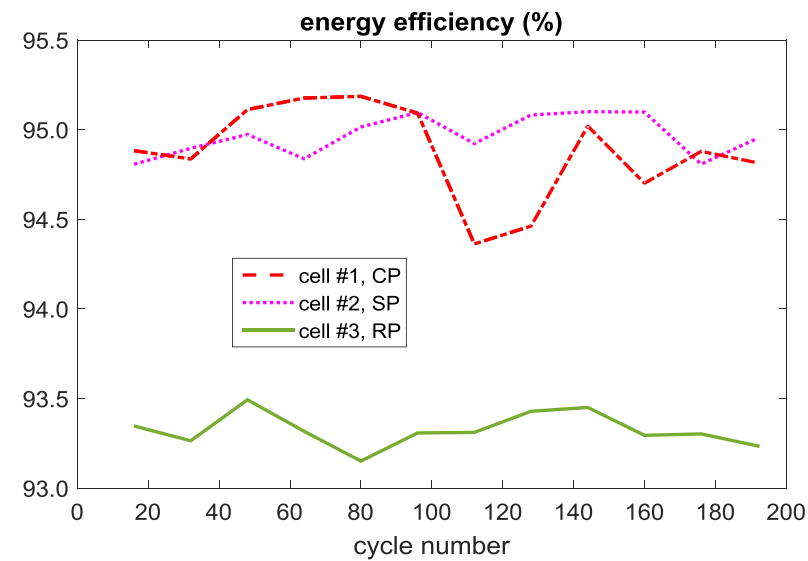

Fig. 7. Round trip energy efficiency of the three cells in the std cycles.

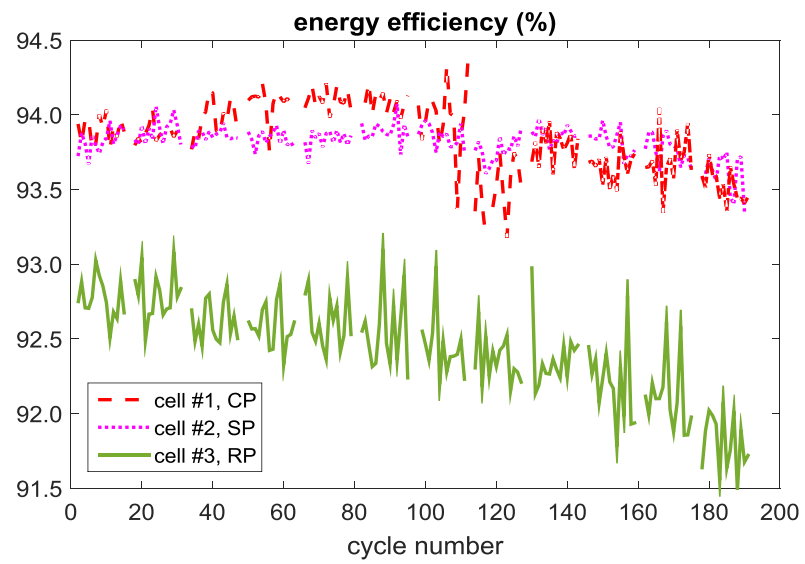

Fig. 8. Round trip efficiency of the three cells in the patterned cycles.

High round trip energy efficiencies of about $94.9 \%$ for cell $\# 1$ and \#2, 93.3\% for cell \#3 are seen in Fig. 7 for the standard charge/discharge cycles. This high energy efficiency hardly changes as the cells age. The usual variation in characteristics between cells is seen here, the lower efficiency of cell \#3 is attributed to its higher initial internal resistance. For the patterned cycles, cell \#3 also showed a relatively low efficiency in Fig. 8. Comparing the energy efficiency of the three cells, we can see that the rate of decrease in cell \#3 was initially greater than in cells $\# 1$ and $\# 2$ and became progressively worse, which matches well with the results of capacity degradation shown in Fig. 6.

\section{Internal Resistance Degradation}

Internal resistance is one of the most important indicators of degradation of a battery. The measured internal resistance $R_{d c}$ at full state of charge of the cells is plotted in Fig. 9. Quadratic polynomial fitting (the three thick curves) has been conducted on the original $R_{d c}$ data to highlight the trends more clearly and also to evaluate the rate of increase (results shown in the legend) of the internal resistance for each case.

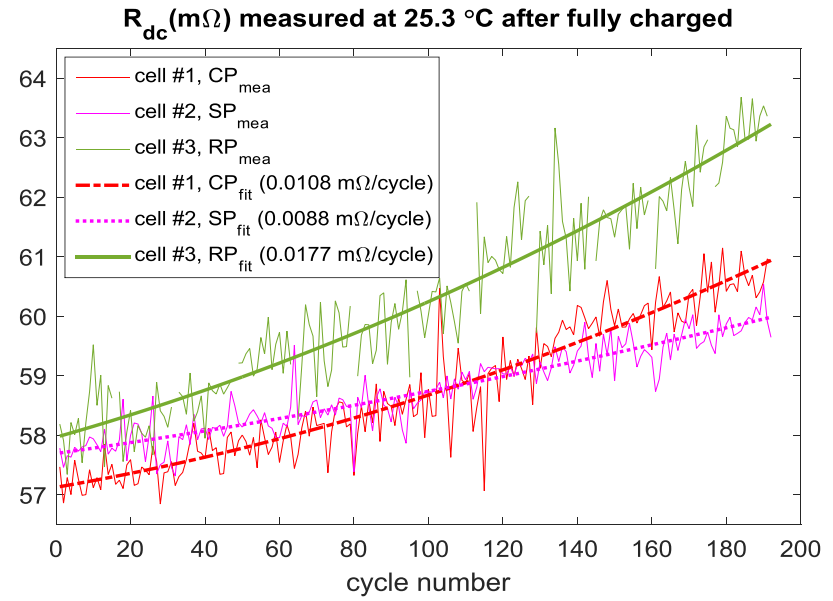

Fig. 9. $R_{d c}$ of the three cells against cycle number. The estimated rate of increase of $R_{d c}$ from the $\mathrm{CP}_{\text {fit }}, \mathrm{SP}_{\text {fit }}$ and $\mathrm{RP}_{\text {fit }}$ curves are $0.0108,0.0088$, and $0.0177 \mathrm{~m} \Omega /$ cycle, respectively, with the negligible quadratic coefficient omitted.

Fig. 9 shows that the cells' internal resistance increases with the cycle number. Cell \#3 showed the highest initial resistance, which was in agreement with the fact that \#3 had lower energy efficiency than the other two cells as seen in Fig. 7 and Fig. 8. Fig. 9 also clearly shows that the rate of increase of $R_{d c}$ of cell \#3 (ramped power test) is the highest of the three, and cell \#2 (stepped power test) has the lowest rate. The different rates of increase of $R_{d c}$ are in accordance with the different capacity degradation rates, as well as the rates of change of the measured energy efficiency of the three cells.

To summarize, the battery cycling tests emulating the three most commonly proposed electric operation regimes for an HEA indicate that the ramped power regime is the worst among the three from the perspective of degrading the cell characteristics, though it has the best block fuel saving potential. High current rate, over-voltage (overcharge), high depth of discharge, and under-voltage are the most influential factors that accelerate degradation of Li-ion batteries. In the ramped power operation regime, the ESS is required to produce the maximum power at the end of cruise, which means a high discharging current towards the end of the mission, when the batteries are at a relatively low SoC and low open circuit voltage. This is thought to be why cell \#3 showed the greatest degradation in the tests. On the contrary, for the stepped power regime, the discharging current is kept at a low level towards the end of the mission, this lower current profile, as shown in Fig. 4(b), leads to a relatively slow degradation rate to the cell $\# 2$, though a short period of high current at the start of the take-off \& climb stage does occur. For the constant power regime, the discharging current at the end of cruise is moderately low, consequently this regime caused a moderate impact on the ageing of cell \#1, similar to that seen for cell \#2 with the stepped profile.

Therefore, a combination of the features of the stepped and ramped operating regimes is thought to be a promising avenue of investigation in order to find an optimal balance between battery degradation and fuel saving. The operating regime would need to trade the fuel burn by the engine with battery use in the early stages of the cruise phase, but limit battery use at low states of charge. 


\section{CONCLUSION}

The hybridisation of aircraft propulsion systems is one of the most promising approaches to achieve the step-change in fuel burn and emissions that is mandated by international targets. However, the practical realisation of hybrid propulsion for mid-range, single-aisle aircraft is predicted to require largescale battery banks of up to $7 \mathrm{MWh}$ and a major increase in battery energy density. A number of operating regimes has been investigated for the hybrid system on-board a future aircraft revealing significant differences in the potential fuel saving across a complete flight cycle.

This paper has examined the impact that three of the most commonly proposed HEA operating regimes are likely to have on battery degradation and life. The reduction in capacity and the increase in dc internal resistance with cycle number were taken as indicators of battery degradation. It has been shown that the battery operating regime which is most effective at reducing overall fuel burn, the ramped profile, is the one that has the most severe impact on battery life. This is attributed to the high current that is drawn from the battery at low state of charge. In contrast the stepped operating regime was found to have the least severe impact on battery life. This conclusion is based on 180 HEA emulating charge/discharge cycles, which resulted in $4-7 \%$ reduction in capacity. Whilst this is likely to be a good indicator of overall battery life, further testing is needed to determine battery life precisely.

These results indicate the importance of investigating further the trade-off between fuel saving and battery life in a future HEA. Whilst future batteries will employ different chemistries to provide the increase in energy density needed for a HEA, the patterns of degradation are likely to be similar to those seen in these experiments, and these results are therefore an indicator of the system trade-offs that will be necessary to optimise performance.

\section{ACKNOWLEDGMENT}

The research was supported by Rolls-Royce through the University Technology Centre (UTC) in Power Conversion at the University of Manchester.

\section{REFERENCES}

[1] K. Bradley Marty and K. Droney Christopher, "Subsonic ultra green aircraft research: Phase I final report," Boeing Research and Technology, CA, Tech. Rep. NASA/CR-2011-216847, Apr. 2011.

[2] M. K. Bradley and C. K. Droney, "Subsonic Ultra Green Aircraft Research. Phase II-Volume II - Hybrid Electric Design Exploration," Boeing Research and Technology, CA, Tech. Rep. NASA/CR-2015218704/Volume II, Apr. 2015.

[3] C. Pornet, et al. "Methodology for Sizing and Performance Assessment of Hybrid Energy Aircraft", J. of Aircraft, Vol. 52, pp. 341-352, 2015.

[4] A. T. Isikveren, C. Pornet, P. C. Vratny, and M. Schmidt, "Conceptual studies of future hybrid-electric regional aircraft," in the 22nd International Symposium on Air Breathing Engines, 2015.

[5] C. Pornet and A. Isikveren, "Conceptual design of hybrid-electric transport aircraft," Progress in Aerosp. Sci., vol. 79, pp. 114-135, 2015.

[6] C. Perullo, D. Trawick, M. Armstrong, J. Tai, and D. N. Mavris, "Cycle Selection and Sizing of a Single-Aisle Transport with the Electricly Variable Engine (EVE) for Fleet Level Fuel Optimization," in 55th AIAA Aerospace Sciences Meeting, pp. 1923, 2017.

[7] Airbus Group Innovations, "E-Thrust", Available: http://company.airbus .com/service/mediacenter/download/?uuid=64ea2c23-91b1-4787-9d1d5b22b7d716b9, May 2018.

[8] G. Zubi, R. Dufo-Lopez, M. Carvalho, and G. Pasaoglu, "The lithiumion battery: State of the art and future perspectives," Renewable \& Sustainable Energy Reviews, vol. 89, pp. 292-308, Jun 2018.

[9] M. Farhadi and O. Mohammed, "Energy Storage Technologies for HighPower Applications," IEEE Trans. Ind. Appl., vol. 52, pp. 1953-1961, 2016.

[10] J. L. Mathieu and J. A. Taylor, "Controlling nonlinear batteries for power systems: Trading off performance and battery life," 2016 Power Systems Computation Conference (PSCC), Genoa, 2016, pp. 1-7.

[11] L. Tang, G. Rizzoni, and M. Lukas, "Comparison of dynamic programming-based energy management strategies including battery life optimization," in 2016 ESARS-ITEC, 2016, pp. 1-6.

[12] Panasonic, "Specifications of Lithium Ion Battery (Cylindrical Type)", Energy Company of Panasonic Group, Rep. NCR18650-068, May 2012.

[13] A. D. Pizzo, L. P. D. Noia, and F. Marulo, "Design considerations on energy storage system for electric aircraft propulsion," in 2016 AEIT International Annual Conference (AEIT), 2016, pp. 1-6.

[14] K. V. Papathakis, et al. "Design and development of a 200-kw turboelectric distributed propulsion testbed" in 52nd AIAA/SAE/ASEE Joint Propulsion Conference, Salt Lake City, 2016. 